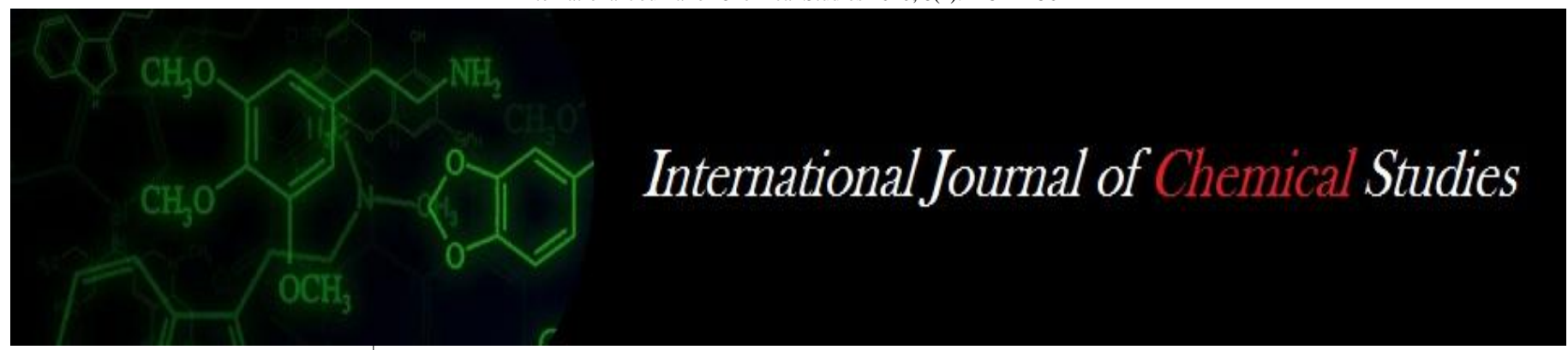

P-ISSN: 2349-8528

E-ISSN: 2321-4902

IJCS 2020; 8(1): 2254-2256

(C) 2020 IJCS

Received: 27-11-2019

Accepted: 29-12-2019

\section{Madhuri Singh}

Department of Genetics and

Plant Breeding, College of

Agriculture, Indira Gandhi

Krishi Vishwavidyalaya, Raipur,

Chhattisgarh, India

Prabharani Chaudhari

Department of Genetics and

Plant Breeding, College of

Agriculture, Indira Gandhi

Krishi Vishwavidyalaya, Raipur,

Chhattisgarh, India

\section{Sandeep Bhandarkar}

Department of Genetics and

Plant Breeding, College of

Agriculture, Indira Gandhi

Krishi Vishwavidyalaya, Raipur,

Chhattisgarh, India

\section{Laxmi Singh}

Department of Genetics and

Plant Breeding, College of

Agriculture, Indira Gandhi

Krishi Vishwavidyalaya, Raipur,

Chhattisgarh, India
Corresponding Author:

Madhuri Singh

Department of Genetics and

Plant Breeding, College of

Agriculture, Indira Gandhi

Krishi Vishwavidyalaya, Raipur,

Chhattisgarh, India

\section{Studies on genetic divergence analysis in rice germplasm (Oryza sativa $\mathbf{L}$.)}

\author{
Madhuri Singh, Prabharani Chaudhari, Sandeep Bhandarkar and Laxmi \\ Singh
}

DOI: https://doi.org/10.22271/chemi.2020.v8.i1ah.8608

\begin{abstract}
Genetic diversity among fifty rice germplasm was evaluated analysis of variance revealed the presence of considerable amount of variability among the germplasm. Based on cluster analysis, the germplasm were grouped into five clusters. For quantitative traits the cluster II comprised of 17 making the biggest bunch, subsequently, cluster IV constituted 13, cluster I constituted 9, cluster III constituted 6, and clustered V constituted 5 accessions. This type of pattern of cluster group confirms the continuation of significant number of variability. The maximum inter cluster distance among cluster III and IV and inter cluster distance minimum was recorded among cluster II and IV. Cluster I showed highest mean value for harvest index and grain yield per plant, cluster II for thousand grain weight, cluster III for days to $50 \%$ flowering and panicle numbers per plant. Cluster IV contained genotypes for plant height, panicle length of main axis and cluster $\mathrm{V}$ contained genotypes for effective tillers per plant, leaf length and width of blade. The germplasm falling in different clusters with high mean for grain yield and other component characters can be utilized for hybridization programme to obtain elite segregants. These traits, hence could be focused for selection while improving grain yield.
\end{abstract}

Keywords: genetic divergence, cluster analysis, yield attributes and rice.

\section{Introduction}

Rice is prime food crop of India, producing $43 \%$ of caloric requirement for more than $70 \%$ Indian population. Rice gives a great wealth of material for genetical studies because of its wide ecological distribution and enormous discrepancies encountered for multitudinous morphological and physiological characteristic. The Rice germplasm provide with ample of genetic diversity and a treasury of valuable genes. It is a rich pool of important genes that plant breeders can exploit for crop improvement (Yadav et al., 2013).

Genetic diversity is the pre-requisite for any crop improvement programme because it helps in the development of superior recombinants (Manonmani and Fazlullah Khan 2003), through selection of parents having wider variability for different characters (Nayak et al. 2004). Genetic divergence analysis evaluates the genetical distance among the selected genotypes and shows the relative contribution of specific traits towards the total divergence. A higher heterosis could be achieved from crosses between genetically distant parents (Falconer 1960). Therefore, the present investigation aimed to assess the nature and magnitude of genetic divergence present in the fifty rice germplasm and to select suitable diverse genotypes as parents for further utilization in crop improvement program.

A major purpose of varietal characterization is to establish the distinctiveness between the germplasm and also to establish their unique detection profiles on the basis of grouping individuality prescribed by Distinctness Uniformity Stability (DUS) guidelines. Morphological description is the first step for classification and evaluation of the germplasm which is a necessary tool for selecting varieties or lines based on agronomical, morphological, genetic or physiological characters. Rice occupied average of 3.6 million hectare area having productivity range between 1.2 to $1.6 \mathrm{t} / \mathrm{ha}$ depending upon the rainfall in Chhattisgarh. The adjoining area of Orissa and Chhattisgarh are considered to be the store house of vast genetic variability. The efficiency of selection depends upon the magnitude of genetic variability present in the plant population. thus, the surfaces of genetic improvement in any characters depends upon the nature of variability present in the gene pool for that character, to start a judicious plant breeding programme.

\section{Material and Method}

Fifty indigenous rice germplasm were grown in randomized complete block design with two replications at the Research cum Instructional Farm, Department of Genetics and Plant 
Breeding, College of Agriculture, Indira Gandhi Krishi Vishwavidyalaya, Raipur, Chhattisgarh during Kharif 2018. Each entry was sown where row to row spacing was $20 \mathrm{~cm}$ and plant to plant spacing was $15 \mathrm{~cm}$. Crop was raised following recommended package of practices.

\section{Observation recorded:}

Observations were recorded on five randomly tagged plants of each genotype per replication. Data were recorded on 11 quantitative characters which includes Days to $50 \%$ flowering, Plant height $(\mathrm{cm})$, Effective number of tillers/ plant, Leaf length of blade $(\mathrm{cm})$, Leaf width of blade $(\mathrm{cm})$, Panicle length of main axis $(\mathrm{cm})$, Panicle number / plant, Thousand grain weight (g), Biological yield/ plant (g), Harvest index (\%), and Grain yield/plant(g).
In the current study, Euclidian distance between genotypes was estimated from the standardized data matrix by Unweighted Pair Group Method using Arithmetic Averages (UPGMA) method and clustering was done by Agglomerative Hierarchical method using XLSTAT 2014 software."

\section{Results and Discussion}

Analysis of variance was based on the mean values of quantitative traits observed for fifty rice germplasm. The analysis of variance indicated the existence of highly significant differences among genotypes for all the characters studied in Table 1 . This indicated presence of high variability among the genotypes, which provides ample scope for selection for different quantitative characters.

Table 1: Analysis of variance for different Quantitative characters

\begin{tabular}{|c|c|c|c|c|}
\hline S. No. & Sources of variation & \multicolumn{2}{|c|}{ Mean sum of square } & Treatment \\
\hline & & Replication & 49 & Error \\
\hline & Degree of freedom & 1 & 49 \\
\hline 1 & Days to 50\% flowering & 2.56 & $139.12^{* *}$ & 0.457 \\
\hline 2 & Plant height (cm) & 1.37 & $993.42^{* *}$ & 35.76 \\
\hline 3 & Effective tillers per plant & 0.22 & $11.48^{* *}$ & 0.49 \\
\hline 4 & Leaf length of blade (cm) & 0.25 & $63.03^{* *}$ & 0.29 \\
\hline 5 & Leaf width of blade (cm) & 0.019 & $0.079^{* *}$ & 0.0074 \\
\hline 6 & Panicle length of main axis (cm) & 7.74 & $14.37^{* *}$ & 3.17 \\
\hline 7 & Panicle no. per plant & 2.78 & $2.51^{* *}$ & 1.78 \\
\hline 8 & Thousand grain weight (gm) & 0.15 & $57.51^{* *}$ & 0.18 \\
\hline 9 & Biological yield per plant (gm) & 3.83 & $140.97^{* *}$ & 17.16 \\
\hline 10 & Harvest index (\%) & 24.73 & $314.64^{* *}$ & 38.02 \\
\hline 11 & Grain yield per plant (gm) & 3.38 & $31.95^{* *}$ & 5.87 \\
\hline
\end{tabular}

(Note- ** Significant at $1 \%$ level of probability, * Significant at $5 \%$ level of probability)

The 50 germplasm accessions are distributed into 5 clusters. Between the clusters the accessions were not evenly distributed. The cluster II comprised of 17 accessions, followed by cluster IV constituted of 13 accessions, cluster I constituted by 9 accessions, cluster III cluster constituted of 6 and $\mathrm{V}$ cluster constituted 5 accessions. The pattern of collection proved the survival of remarkable amount of variability.

Table 2: Distribution of 50 germplasm accessions among five clusters for quantitative characters

\begin{tabular}{|c|c|c|}
\hline Cluster No. & No. of genotypes in each cluster & Name of genotypes \\
\hline I & 9 & $\begin{array}{c}\text { Lal dhan, Nagkeshar, Paveetra, Krishnanjan, Maharaji, Swarna, MTU 1010, } \\
\text { Zinc rice -2, Madhuraj dhan -55 }\end{array}$ \\
\hline II & 17 & $\begin{array}{c}\text { Karanga, Lal banko, Nagpuri gurmatiya, Ramshri, Parra, Barhasaal, R-RKM- } \\
\text { 1, Sendur singha, Danwar, Baisoor, Resari, Soth, Mehardhan, Chepti } \\
\text { gurmatiya, IR-64, Zinc rice-1 }\end{array}$ \\
\hline III & 6 & Sathi, Kalajeera, Jauphool, Tilkasturi, Suldhan, Chaptimathyala \\
\hline IV & 13 & $\begin{array}{c}\text { Raj banko, Khutbuti, Kalimuch, Sathaka, Aalcha, Bora, hundar, Sathaka, } \\
\text { Parwatkala, Karangi, Gathwan, Laycha, Saraiphool }\end{array}$ \\
\hline V & 5 & Davar, Korma, Kujjii, Bhejari, Karhani \\
\hline
\end{tabular}

The inter and intra cluster distances between five clusters were calculated and have been listed in Table 3. The inter and intra cluster distances between five clusters were calculated and have been listed in Table 4.7. The intra cluster distance range from $2.048(\mathrm{~V})$ to 2.545 (IV). The inter cluster distance was maximum between cluster III and cluster V (4.49) and minimum inter cluster distance was recorded among cluster II and IV (2.866).

Table 3: Distance between cluster centroids (intra and inter cluster $\mathrm{D}^{2}$ values)

\begin{tabular}{|c|c|c|c|c|c|}
\hline Class & I & II & III & IV & V \\
\hline I & 2.161 & 2.972 & 3.197 & 3.6 & 4.087 \\
\hline II & & 2.373 & 4.279 & 2.866 & 3.346 \\
\hline III & & & 2.544 & 3.91 & 4.49 \\
\hline IV & & & & 2.545 & 4.082 \\
\hline V & & & & & 2.048 \\
\hline
\end{tabular}

The cluster mean data exhibited a broader range of variations for all the traits undertaken in the studied Table 4. Cluster I showed highest mean value for harvest index (54.08), grain yield per plant (14.76), whereas cluster II comprised genotype with highest mean value for thousand grain weight (27.21). Cluster III for days to $50 \%$ flowering (100.33) and panicle 
number per plant (8.63). Cluster IV contained genotype with highest mean value for plant height (141.07), panicle length of main axis (25.73). While cluster $\mathrm{V}$ contained genotype with highest mean value for effective tiller per plant (11.8), leaf length of blade (42.93), leaf width of blade (0.99) and biological yield per plant (36.41). Similar findings were revealed by Medhabati et al. (2012). Kumari et al. (2018).

Table 4: Cluster mean values of five clusters for different quantitative characters

\begin{tabular}{|c|c|c|c|c|c|c|c|c|c|c|c|}
\hline Class & DTF & PH (cm) & ET & LLB (cm) & LWB (cm) & PLMA (cm) & PNPP & 1000 gw (g) & BYPP (g) & HI (\%) & GYPP (\%) \\
\hline I & 92.83 & 101.2 & 6.98 & 30.85 & 0.64 & 22.46 & 7.49 & 22.62 & 28.36 & 54.08 & 14.76 \\
\hline II & 86.5 & 116.35 & 6.67 & 37.62 & 0.82 & 23.23 & 6.24 & 27.21 & 25.06 & 38.62 & 9.3 \\
\hline III & 100.33 & 125.47 & 10.22 & 35.85 & 0.67 & 25.62 & 8.63 & 16.02 & 34.93 & 41.45 & 14.12 \\
\hline IV & 97.65 & 141.07 & 6.58 & 41.76 & 0.94 & 25.73 & 6.03 & 25 & 28.82 & 52.41 & 14.62 \\
\hline V & 84.7 & 90.87 & 11.8 & 42.93 & 0.99 & 21.94 & 6.56 & 27.16 & 36.41 & 39.2 & 14.1 \\
\hline
\end{tabular}

Note- DTF= Days to 50\% flowering, $\mathrm{PH}=$ Plant height, ET= Effective tillers per plant, $\mathrm{LLB}=$ Leaf length $\mathrm{f}$ blade, $\mathrm{LWB}=$ Leaf width of blade, PLMA = Panicle length of main axis, PNPP $=$ Panicle number per plant, $1000 \mathrm{gw}=\mathrm{Thousand}$ grain weight, $\mathrm{BYPP}=$ Biological yield per plant, $\mathrm{HI} \%=$ Harvest index Percentage

\section{Conclusion}

A significant range of variation was evident among fifty rice germplasm; evaluated. In cluster analysis fifty germplasm accessions/varieties were distributed into five clusters. The parents for hybridization program should be selected on the basis of magnitude of genetic distance, contribution of different characters towards the total divergence and magnitude of cluster means for different characters performance having maximum heterosis. The maximum inter cluster distance among cluster III and IV and inter cluster distance minimum was recorded among cluster II and IV. Crosses between the germplasm of clusters III and IV, are expected to manifest high heterosis along with, accumulation of favourable genes in subsequent segregating generations.

Cluster I showed highest mean value for harvest index and grain yield per plant, cluster II for thousand grain weight, cluster III for days to $50 \%$ flowering and panicle numbers per plant. Cluster IV contained genotypes for plant height, panicle length of main axis and cluster $\mathrm{V}$ contained genotypes for effective tillers per plant, leaf length and width of blade. These traits, hence could be focused for selection while improving grain yield.

\section{References}

1. Asish K, Binodh R Kalaiyarasi, Thiyagarajan K. Genetic divergence of rice varieties and hybrids for quality traits. Oryza. 2010; 47(2):91-95.

2. Ayesha B, Abbasi FM, Rabbani MA, Khatiba B. Genetic diversity assessment of indigenous rice germplasm from northern Pakistan using agro morphometric traits. Pak. J Bot. 2015; 47(3):1061-1067.

3. Kumar B, Gupta B, Singh B. Genetic diversity for morphological and quality traits in rice (Oryza sativa L.). The Bioscan. 2014; 9(4):1759-1762.

4. Kumari RV, Rangasamy P. Studies on genetic diversity in international early rice genotypes. Ann. Agric. Res. 1997; 18:29-33.

5. Ovung CY, Lal GM, Kumar Rai P. Studies on genetic diversity in Rice (Oryza sativa L.). Journal of Agricultural Technology. 2012; 8(3):1059-1065.

6. Manonmani S, Fazlullah Khan. Analysis of genetic diversity for selection of parents in rice. Oryza. 2003; 40:54-56.

7. Medhabati K, Kangabam Rajiv, Rohinikumar M, Devi Huidrom, Dikash Thingbaijam. Genetic Divergence in Indigenous Wild and Cultivated Rice Species of Manipur Valley. ISRN genetics, 2012.

8. Nayak AR, Chaudhury D, Reddy JN. Genetic divergence in scented rice. Oryza. 2004; 41:79-82.
9. Richharia RH. An Aspect of Genetic Diversity in rice. Oryza. 1979; 16:1-31.

10. Sarawagi AK, Ojha GC, Koshta N, Pachauri A. Genetic divergence and association study for grain yield in rice (Oryza sativa L.) germplasm accessions. The Ecoscan, 2015; 9(1-2):217-223.

11. Shivani DK, Dwivedi RH, Kunvar G, Khan NA. Genetic Divergence for Yield and Other Quantitative Traits in Rice (Oryza sativa L.). Int. J Curr. Microbiol. App. Sci. 2018; 7(01):1201-1207.

12. Singh G, Kumar P, Kumar R, Gangwar L. Genetic diversity analysis for various morphological and quality traits in bread wheat (Triticum aestivum L.). Journal of Applied and Natural Science. 2018; 10:24-29.

13. Sowmiya CA, Venkatesan M. Studies on Genetic Diverity in Rice (Oryza Sativa L.). Int. J Curr. Microbiol. App. Sci. 2017; 6(9):1749-1756.

14. Thomson MJ, Septiningsih EM, Suwardjo F, Santoso TJ, Silitonga TS, McCouch SR et al. Genetic diversity analysis of traditional and improved Indonesian rice (Oryza sativa L.) germplasm using microsatellite markers. Theor. Appl. Genet. 2007; 114:559-568.

15. Yadav S, Singh A, Singh MR, Goel N, Vinod KK, Mohapatra $\mathrm{T}$ et al. Assessment of genetic diversity in Indian rice germplasm (Oryza sativa L.): use of random versus trait-linked microsatellite markers. J Genet. 2013; 92:545-557. 